\title{
逆浸透法における操作因子および輸送 モデルに関する研究 \\ MODEL AND OPERATING FACTORS FOR TRANSPORT PROPERTIES OF OSMOTIC MEMBRANE
}

\author{
岩 井 重 久*・北尾 高 嶺**.菅 原 正 孝*** \\ By Shigehisa IWAI, Takane KITAO and Masataka SUGAWARA
}

\section{1. 緒言}

逆浸透法は半透膜の有する選択透過性を利用し，圧力 を推進力として, 溶媒と溶質の間, あるいは溶質間の分 離, 濃縮をはかる膜分離法である. 本法は, 元来, 海水 の淡水化技術として研究開発されてきたものであるが, 近年, 本法の分離対象物質の多様性と分離性能の高度さ などの点から, 脱塩だけでなく, 他の多くの分野での応 用研究も盛んになった. とくに, 用・廃水処理技術の分 野においては, 廃水の高度処理プロセスとして, また, 工場の水使用におけるクローズドサイクルシステムのた めの単位操作の一つとして注目を集めている.

しかし，原液をたんに膜を通して加圧透過させるだけ

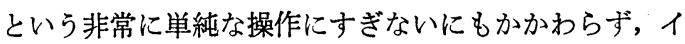
オンなど数 $\AA$ 程度の粒径の溶質が高度に分離されうる ことを理由ゔける透過機構に関する定説は, いまだに確 立されていない.さらには, 膜を介した物質輸送につい てさえ, 研究者間でかならずしも合意がえられた数式モ デルが確立されているとは言えず, そのために逆浸透現 象に関する解析方法も多岐にわたっている.

Merten らは ${ }^{1)}$ ，水および塩は，まず膜内に溶解し， その後, 低圧側に向って膜内を拡散するとの仮定に基づ いた物質輸送モデルを提案した. このモデルでは, 物質 の移動を引き起す推進力を膜の高圧側と低圧側の濃度差 にあると仮定して, Fick の法則を適用している.した がって, 本モデルによると溶質の移動速度は操作圧力に かかわらず一定となる. しかし, 多くの研究者の報告に もみられるように ${ }^{2) ~ 5)}$, 一般に溶質の移動速度は, 操作 圧力により変化するという特性を有していることから， 現象を正しく表現していると認められない.さらに，水

* 正会員 工博 京都大学教授 工学部衛生工学科

** 正会員 工博 京都大学助教授 工学部衛生工学科

*** 正会員 工修 京都大学助手 工学部衛生工学科
と塩は，相互に干涉することなく，まったく独立に膜内 を抎散するという仮定は, 膜を均質な拡散障壁とみなし ている点とも併せて, 妥当性に乏しい. そこで, 水と塩 との相互作用を考慮した モデルとして, Spiegler らに よる非平衡熱力学による取扱いがある ${ }^{6)}$. このモデルに よれば, 溶質の移動は, 拡散項と移流項とで表示しらる ので, 操作圧力と溶質移動が関連つけられている.この ように, 溶解拡散モデルよりは溶質透過の現象をより的 確に表現しうる点では, Spiegler らのモデルは一歩進 んだ数式モデルと言える.

しかし，以上のモデルにおいては，いずれも膜の微細 構造を考慮しないで，膜をたんなるブラックボックスと して扱っている. したがって，式中の係数の物理的な意 味があいまいであるなど具体性に欠けるが，現象論的な 輸送式としては, Spiegler らの式は有用である.

このように膜を均質媒体として取扱うのではなく, 膜 が実質部と空隚部より成るとして，物質移動現象のモデ ル化を試みている研究者も多い. その大部分は, 溶質の 輸送は, 拡散流と粘性流の 2 つの流れに基ゔくと考えて いる点で共通しているが, これらのモデルの基本概念に はそれぞれ若干の違いがある. 著者らも，膜が多孔性で あるという見地に立っているが，本研究では，物質輸送 のモデル式を提示し，その妥当性ならびに溶質移動を支 配する操作因子に対して実験的な検討を加えた.

\section{2. 物質輸送モデル}

\section{（1）既応の多孔膜物質輸送モデル}

膜を不均質, 疎密の分布を有するものとみなして, 物 質輸送現象のモデル化がなされたものをいくつかあげ て，それらの基本概念およびモデル式中の諸係数の物理 化学的な意味を検討する.

Sherwood らは4), 水および溶質は, 搪散流と細孔流 
との両者を通じて膜内を移動するとの仮定のもとに, 次 式を提示した.

$$
\begin{aligned}
& J_{s}=k_{s} M_{s}\left(C_{h}-C_{l}\right)+k_{v} M_{s} \Delta P_{r} C_{h} \\
& J_{w}=k_{w}\left(\Delta P_{r}-\Delta \pi\right)+k_{v} M_{w} \Delta P_{r} C_{h}{ }^{\prime} .
\end{aligned}
$$

ここに, $J_{s}$ は溶質の流束, $J_{w}$ は水の流束, $k_{w}, k_{v}, k_{s}$ はそれぞれ水の拡散, 細孔流, 溶質の拡散に対する膜係 数, $C_{h}, C_{h}{ }^{\prime}$ は, 高圧側膜面における溶質および水の濃 度, $C_{l}$ は透過水の溶質濃度, $M_{s}, M_{w}$ は溶質および水 の分子量, $\Delta P_{r}$ は膜の両側の圧力差, $\Delta \pi$ は膜の両側の 液の浸透圧差である.このモデルでは, 拡散は膜の実質 部つまり膜の主成分である高分子物質が密に配列してい る結晶性部分にて起こり, 細孔部においては, 溶質濃度 は変化せず 同一濃度のまま膜内を通過するとしている が,これは細孔をたんに溶液が漏れ出てくる欠陥構造で あると考え，その部分にまったく排除機能をもたせてい ない. したがって, 水および溶質の相互不干涉の仮定を も含めて, 本モデルは, 本質的には溶解拡散型のモデル と同じ考えに立つものと思われる.

Michaels らは2)，アルカリ金属塩を用いた実験結果 から溶質の輸送モデルとして次式を提示し, 諸俰数の検 討を行っている.

$$
J_{s}=\left(a+b \Delta P_{r}\right) C_{h}
$$

ここに, $a, b$ はパラメーターである.これによると,イ オンの移動は, 実質部と細孔部の両者において起こり, 前者は濃度差を推進力とした 拡散流で占められている が, 後者のうち孔径が分子オーダーの細孔では, 圧力勾 配と濃度差に支配される活性化拡散の存在を仮定しなけ ればならないとしている，したがって，圧力に依存しな い第一項は, 実質部での移動量を表わしている. 第二項 は, たんなる体積流ではなく, パラメーターbの值は, イオンの水和半径に依存する.また，水は実質部のなか を分子拡散により輸送されるとした.

Yasuda らは7), 分子オーダーの孔は, 定常的な孔で はなく, 分子のよう動による孔と考え, 自由体積理論に よって物質輸送モデルを立てたが，拡散流だけの場合を 完全な膜とし, 粘性流には塩の排除機能を認めていない など取り扱いそのものは溶解拡散型とほぼ同様である.

$$
\begin{aligned}
& J_{w}=J_{w, f}+J_{w, d} \\
& J_{s}=\left[K_{w}-P_{w} v_{w} / R T\right]\left[\left(\Delta P_{r}-\Delta \pi\right) / \Delta X\right] C_{h} \\
& +P_{s}\left[\left(C_{h}-C_{l}\right) / \Delta X\right]
\end{aligned}
$$

ここに, $J_{w, f}, J_{w, d}$ は水の粘性流 および拡散流, $R$ は 気体定数, $T$ は絶対温度, $\Delta X$ は膜の有効厚さ, $P_{s}$ は 塩の膜中拡散係数である. 式 (5) の第一項は 粘性流, 第二項は拡散流による塩の輸送を表わす.また， $K_{w}, P_{w}$ は, 水の膜透過性に関して次のように定義される係数で あり, $v_{w}$ は水のモル体積である.

$$
J_{w, d}=P_{w}(\Delta C / \Delta X)
$$

$$
J_{w, f}=K_{w}\left(\Delta P_{r} / \Delta X\right)
$$

ここに, $\Delta C$ は膜の両側の濃度差である.したがって, 塩の移動に関する圧力依存項は塩の種類によらず一定で あり, 水の膜透過性だけで決定される.

以上のモデルでは, 膜中に細孔の存在を仮定している が, 物質の輸送は, 細孔部および実質部のいずれの場に おいても起こっているとして解析している. これらに対 し, Sourirajan らは, その一連の研究を通じて, 水, 塩などの物質はすべて細孔部を通って輸送されるとした 選択的吸着モデルを提示している ${ }^{8)}$. しかしながら, 彼 らの用いた具体的な数式モデルは, 濃度分極現象を考慮 しているが，本質的には Merten らの溶解拡散型とま ったく同じものであり, 種々の実験データから判断して も，かならずしも輸送現象を的確に表現しているものと は考えにくい.

\section{（2）モデルの概要}

著者らは，膜を多孔性物質であるとして，水および溶 質は Sourirajan らと同様に細孔部を通って輸送される と考えた. このように膜の構造を規定するとともに, 水 および溶質は，細孔内を膜の実質部との相互作用をうけ つつ拡散流と粘性流により膜中を移動するとして, 水透 過速度 $J_{v}$ と溶質透過速度 $J_{s}$ を次のように表わした.

$$
\begin{aligned}
& J_{v}=A\left(\Delta P_{r}-\Delta \pi\right) \cdots \\
& J_{s}=P_{s} \frac{\Delta C}{\Delta X}+\varepsilon J_{v} C_{h}
\end{aligned}
$$

ここに, $A$ は水透過係数, $\varepsilon$ はパラメーターである.こ のモデルでは, 溶質の移動は, 粘性流と拡散流に基づく とし, さらに粘性流は, 膜や溶質の物理化学的特性, 膜 と溶質との相互作用などによって固有の濃度を有してお り, また, 易動性も異なる. 抬散流についても同様な物 理化学的特性により変化する.すなわち, 溶質種によっ て $P_{s}, \varepsilon, A$ の諸係数が変化すると考えた.

これらの係数值を規定する因子としては, 溶質の物理 化学的特性 (電離度, イオン価, 水和径など), 膜の物 理化学的性質(細孔の大きさおよびその分布, 膜の誘電 率, 電位, 膜の有効厚さなど), 膜と溶質との 親和性さ らには共存する溶質や $\mathrm{pH}$, 温度などの 液特性が考えら れる.

本研究においては, 式 (8), (9) の適用の可能性を検 討し, 水および溶質の膜透過に対する影響因子のいくつ かを明らかにしょらとした。

\section{3. 実験装置および方法}

実験には，2 台の回分式のガス加圧型逆浸透装置を用 いた.槽内には,膜面上での濃度分極を最小限にとどめる 


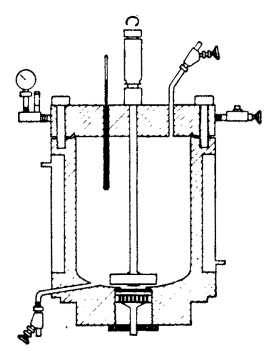

Fig. 1 Reverse osmosis apparatus (Atype).

Table 1 Outline of reverse osmosis apparatus.

\begin{tabular}{|c|c|c|c|}
\hline & A-type & B-type & る. また,加圧には,圧 \\
\hline $\begin{array}{l}\text { Jeed solution } \\
\text { volume }(l)\end{array}$ & 5.0 & 1.4 & 縮窒素ガスを用いた。 \\
\hline $\begin{array}{l}\text { Membrane } \\
\text { area }\left(\mathrm{cm}^{2}\right)\end{array}$ & 9.0 & 67.2 & $\begin{array}{l}\text { なお, Fig. 1, } 2 \text { にそれ } \\
\text { ぞれA型およで } \mathrm{B} \text { 型の }\end{array}$ \\
\hline
\end{tabular}

装置の断面を示す. Table 1 には各装置の概要を示す. 逆浸透装置の底部に取り付ける膜は, Loeb らの製法 に準じて作製したものと采，市販品（Eastman 社製 KP -90)の 2 種類を使用した．前者の製膜工程は以下のとお りである.まず，セルロースアセテート（Eastman 社 製，398-3)，ホルムアミド, アセトンを $25: 30: 45$ の 重量比で混合したキャスト液をつくり，20 22 ${ }^{\circ} \mathrm{C}$ の雾 囲気のもとでガラス板に任意の厚さ $(100 \sim 200 \mu \mathrm{m})$ の 膜をひき，溶媒であるアセトンを 30 秒間蒸発させたの ち, 膜をガラス板とともに 2 時間以上 $5^{\circ} \mathrm{C}$ 以下の冷水 中に浸漬して溶媒を溶出させた. このようにしてつくっ た膜を $79 \pm 1^{\circ} \mathrm{C}$ の温水中で 10 分間熱処理した.さら に, 実験に使用するまえに, 膜の安定化を目的として, $40 \sim 50 \mathrm{~kg} / \mathrm{cm}^{2}$ の圧力で 1 日以上の圧密処理を施した. なお, 実験に使用した膜のうち,このようにしてつくっ た私製膜には K, Eastman 社製膜には $\mathrm{E}$ という記号を 使用し，膜番号の前につけて区別する.

実験に供した試料溶液は, 特級試薬を蒸留水に溶解し て作成した. 溶液濃度は, 浸透圧が無視しらる程度に保 つため, ほとんどの場合約 $10^{-3} \mathrm{~mol} / l$ に調整した. な お, 金属塩の溶解との関連で問題になる溶液の $\mathrm{pH}$ は, 本実験においては 3.4 6.3 の範囲にあった.

次に実験方法について述べる. まず，所定の温度に調 整した原液試料を逆浸透装置の槽内に入れ，500 800 $\mathrm{rpm}$ で擋拌を続けながら, 目的とする操作圧力をかけ るためにボンべより窒素ガスを槽内に導入する. 加圧後 は透過水濃度がほぼ安定しはじめた時点から透過水を秤 量ビンで採取する. 一定時間間隔で 2 3 回採取する. ただし，これら採取時間や採取量などは，圧力や温度な
どの操作条件によりそれぞれ若干異なる. また, 実験中 の槽内試料温度を一定に保つために, 恒温室で実験を行 うとか, 槽周辺に水温一定の循環水を通すなどの方法を 用いた. 採取した透過水は, 化学天秤でその重量を測定 して透過量を求めた. そして, 最後に採取した試料を透 過水の濃度測定に用いた。 また, 槽内の原水濃度は, 実 験中に徐々に高くなるので, 実験終了時に槽内に残留し ている液を高圧側溶液とみなし, この液濃度を原水濃度 として排除率などの計算に用いた.

溶液濃度の測定は, 原子吸光分光光度計 (Jarrel Ash A-1) と電気電導度計 (TOA FU-22 A 型) によった.

\section{（2）膜内拡散係数の測定}

溶質の膜内㧪散係数の測定には, Fig. 3 および Fig. 4 に示す A, B の 2 型式の拡散セルを用いた. A 型セル は, 膜をはさんだ両室の各容量は 約 $9 \mathrm{~m} l$ であり, 膜の有効断面積 は $3.14 \mathrm{~cm}^{2}$ である. B 型セル は, 各室の容積は約 $6 l$ と $\mathrm{A}$ 型 セルとはその規模がまったく異な る. 有効膜面積も $50.3 \mathrm{~cm}^{2}$ と $\mathrm{B}$ 形式の逆浸透装置の有効膜断面積 に匹敵する大きさである. B 型セ ルの各室には, 擋拌子を投入し て、マグネティックスターラーに て擋拌できるように工夫したが,

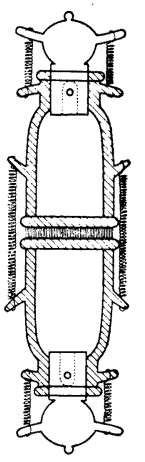

A型セルでは，とくに強制擋拌装 Fig. 3 Apparatus for 置を取り付けていない. diffusion test (A-type).

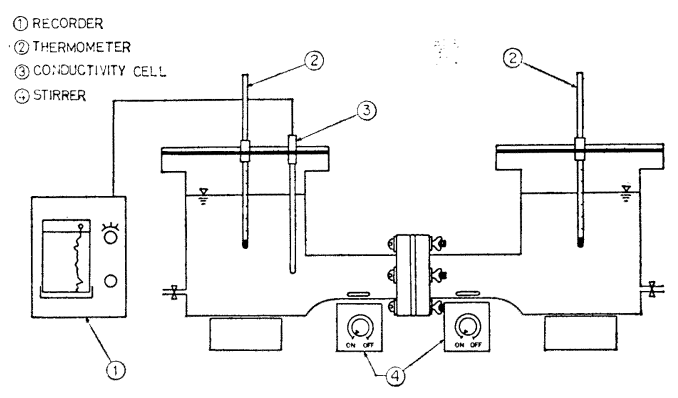

Fig. 4 Apparatus for diffusion test (B-type).

測定操作は, A型と B 型とでは異なる. A 型では, 純 水と溶液を各室に充満させたのち, 各室内の混合が速か に行われるように溶液側を上側, 純水側を下側にして設 㯰する.なお，本研究で用いた膜は非対称膜であるが, 膜はそののち密層が溶液側になるように設定した. そし て, 一定の雾囲気温度条件下で任意時間（通常 3 24 時 間) 放置したのち溶液側と純水側の溶質濃度を原子吸光 分光光度計にて測定する. 一方, B型セルにおいては, 
純水と溶液を各室に $4 l$ ずつ入れて, 擋拌子による混合 を続行しながら，やはり同一䨌囲気温度下で任意時間放 置する．膜のち密層が溶液と接するように膜を設定する のはA型の場合と同じである.そして，純水側の溶質濃 度変化は, 電気電導度計にて連続記録させて求めたり, 場合によっては，ある時間間隔ごとに各室より $5 \mathrm{~m} l$ ず つ採取して，原子吸光分光光度計にて金属濃度を測定す る.

以上のようにして求めた時間と純水側の濃度などから 次式により膜内拡散係数, $P_{s}\left(\mathrm{~cm}^{2} / \mathrm{sec}\right)$ を算出した.

$$
P_{s}=\frac{V_{p} \Delta X}{\left(V_{p} / V i+1\right) A_{m} t} \ln \left\{\frac{1+\left(V_{p} / V_{i}\right)\left(C_{p} / C_{i}\right)}{1-C_{p} / C_{i}}\right\}
$$

ここに, $V_{i}, V_{p}$ は, それぞれ 溶液側, 純水側の室容積 $\left(\mathrm{cm}^{3}\right), C_{i}, C_{p}$ はそれぞれ時間, $t(\mathrm{sec})$ における溶液 側, 純水側の溶質濃度 $(\mathrm{mol} / l), \Delta X$ 漠の有効厚さ $(\mathrm{cm})$ および $A_{m}$ は膜の有効断面積 $\left(\mathrm{cm}^{2}\right)$ である.

なお，測定に用いた膜は，3.(1) で述べたものと同じ である.膜厚は，マイクロメーターで計測し，数か所の 測定值の平均值で表わした。

\section{4. 実験結果および考察}

\section{（1）水透過速度に及ぼす圧力および温度の影響}

単位時間, 単位面積あたりの透過水容積を水透過速度 と定義して, 各種金属塩の水溶液 (濃度は約 $10^{-3} \mathrm{~mol} / l$ ) に対する水透過速度と操作圧力との関倸を Fig. 5 に示
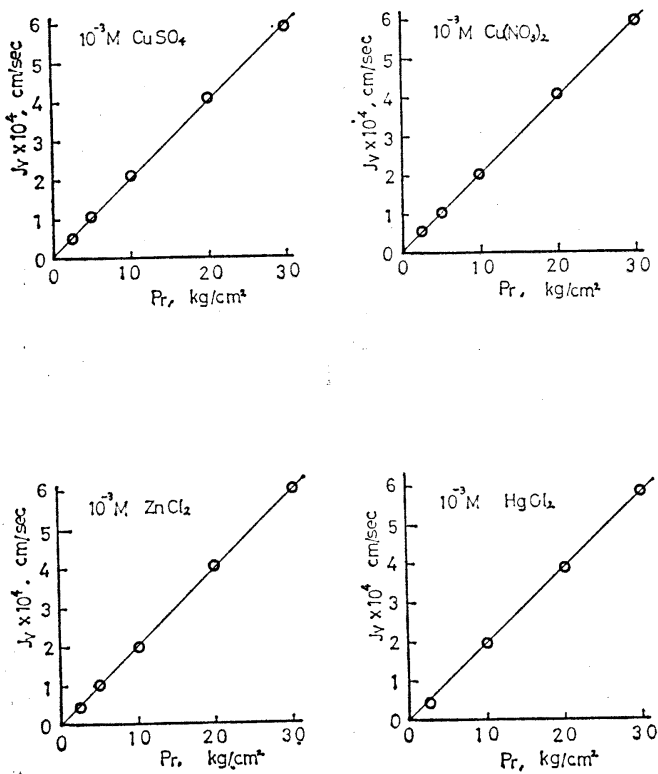

Fig. 5 Water flux vs. driving force at $22^{\circ} \mathrm{C}$ for E-902 membrane.
す.この図に示したように，本実験の操作圧力範囲で は, 水透過速度と操作圧力の間には, ほぼ比例的な関係 が成立している。これは，用いた水溶液が希薄であるた めに, 水溶液の浸透圧, $\pi(=R T C)$ が約 $0.05 \mathrm{~kg} / \mathrm{cm}^{2}$ であり，式（8）において $\Delta \pi \ll \Delta P_{r}$ となるので，結局 次式で近似しうることになる。

$$
J_{v}=A P_{r}
$$

水透過係数, $A$ は本実験では, 溶質の種類には依存し ないようである．それよりも，Aの值は，温度の影響をよ り強く受けると考えられる.そこで，操作圧力を $40 \mathrm{~kg} /$ $\mathrm{cm}^{2}$ に固定し，液温を $4 \sim 30^{\circ} \mathrm{C}$ の間で 数段階に変化さ せて, 水透過速度, $J_{v}$ を求めるとともに, それぞれの 温度における水透過 係数， $A$ を算出し た. 水溶液ではなく て, 純水に対する場 合の $A$ をとくに純水 透過係数と呼ぶ. $A$ の值は, Table 2 に 示したように, 温度 が高いほど大きくな るが, 他方, 各温度

Table 2 Water permeability at various temperature for membrane $\mathrm{K}-331$.

\begin{tabular}{c|c}
\hline $\begin{array}{c}\text { Temperature } \\
\left({ }^{\circ} \mathrm{C}\right)\end{array}$ & $\begin{array}{c}\text { Water permeability } \\
\left(\mathrm{ml} / \mathrm{sec} \cdot \mathrm{cm}^{2} \cdot \mathrm{kg} / \mathrm{cm}^{2}\right)\end{array}$ \\
\hline 4 & $9.60 \times 10^{-6}$ \\
10 & $1.18 \times 10^{-5}$ \\
15 & $1.35 \times 10^{-5}$ \\
20 & $1.52 \times 10^{-5}$ \\
25 & $1.63 \times 10^{-5}$ \\
30 & $1.94 \times 10^{-5}$ \\
\hline
\end{tabular}

における純水および水溶液の $A$ 值と液の粘度, $\eta$ との積 を求め, これを温度に対してプロットすると Fig. 6, 7 のようになる，ただし, 水溶液の粘度は, その濃度が

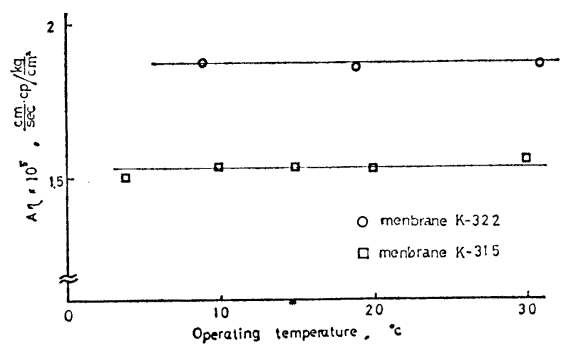

Fig. 6 Effect of temperature on pure water permeability.

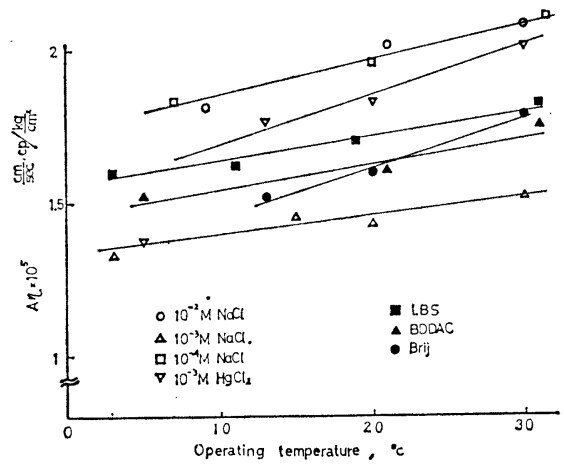

Fig. 7 Effect of temperature on water permeability (Membrane K-311). 
$10^{-3} \mathrm{~mol} / l$ 程度の希薄溶液であるので純水と同一である ものとして取扱ったが，とくに問題はないと思われる ${ }^{10)}$. これより, 純水においては， $A$ と $\eta$ との間には，反比 例の関係が成り立っていることがわかる．純水に関して は，すでに Govindan ら ${ }^{11)}$ も同様の結果をセルロース アセテート膜に対して得ている. 本実験では, とくに水 溶液に対する $A$ の温度依存特性に着目した結果, Fig. 7 で明らかなように, 純水の場合と異なり， $A$ と $\eta$ と の間には反比例の関係がかならずしも成立していない. しかも, $A \eta$ は低温から高温にかけて増加傾向を示す. また, その変化率も溶質によりやや異なる. 本実験で は, わずかの限られた種類の溶質であるが, 電解質であ る. $\mathrm{NaCl}$ に比べて $\mathrm{HgCl}_{2}$ といった非電解性の溶質の ほうが，温度の影響を強く受けていると推察できる.な お，3 種の界面活性剤の例も同時に図示した. 金属塩と 同様な傾向を示している.

水溶液に対する温度の影響 については, Agrawal ら の報告 ${ }^{12)}$ があり，そこではとくに $\mathrm{NaCl}$ 溶液を対象に している.それによると， $0.5 \mathrm{~mol} / l$ の $\mathrm{NaCl}$ 溶液では， 純水と同じく, $A \eta$ は一定であるが, $2.0 \mathrm{~mol} / l$ の NaCl 溶液では, 温度上昇につれて $A \eta$ は減少するという.そ して, その原因を液の密度, 粘度および浸透圧の変化に 求めるとともに，おそらく膜の選択吸着性も温度により 変化を受けているのではないかと述べている.これに対 し本実験では, Agrawal らが対象とした濃度よりもさ らに低い濃度領域の水溶液を用いた結果, $A \eta$ は一定值 を示さず，またその值も温度上昇とともに増加するとい うように, 高濃度域におけるのとはまた違った透過特性 があることがわかった．低濃度域におけるこうした傾向 は, 膜と溶液間の溶質の吸着平衡が，その温度特性など からも，大いに関与している結果として現われているの ではないかと考えられる.そして， 高濃度になるにつれて，浸透圧など の液性が主要因となった透過特性に 変化していくものと思われる。

\section{（2）溶質透過の諸特性}

a) 排除 率

操作圧力と排除率に関する実験結 果を Fig. 8 に示す.ここで，排除 率を次のように定義する.

$$
\text { 排除率 }=1-\frac{\text { 透過水の濃度 }}{\text { 原液の濃度 }}
$$

Fig. 8 より, 排除率の 圧力依存性 に関しては, 圧力の増大につれて排 除率が高くなる傾向があり，とりわ 泜圧域における排除率が大きく変

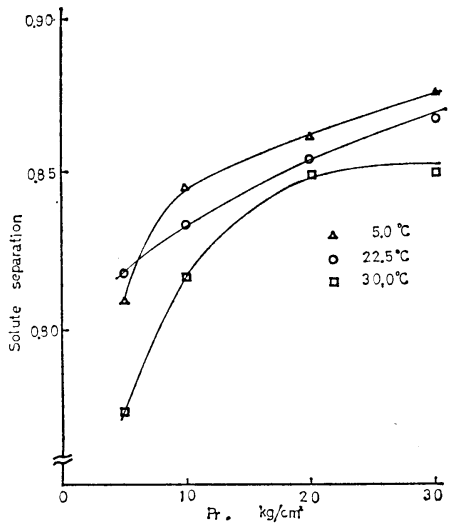

Fig. 9 Solute separation as a function of driving force at various operating temperature. Conditions: $10^{-3} \mathrm{M} \mathrm{NaCl}$ feed solution (Membrane $\mathrm{K}-311$ ).

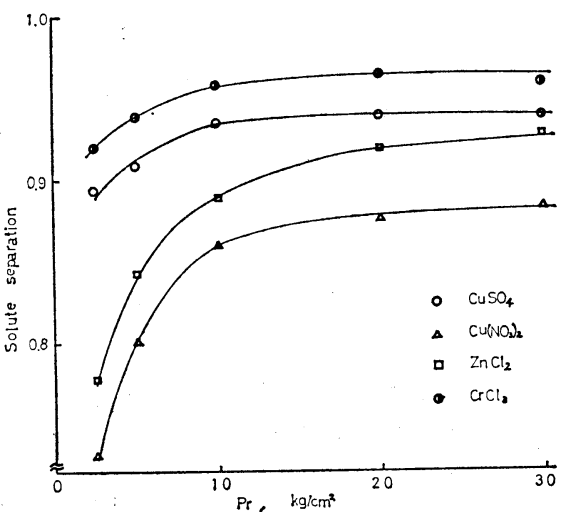

Fig. 8 Solute separation as a function of driving force at $22^{\circ} \mathrm{C}$. Conditions : $10^{-3} \mathrm{M}$ feed solution (Membrane E-902).

化すると言える.こうした排除率 の圧力依存特性は, $\mathrm{NaCl}$ をはじめとする 金属塩に対しても報告されてい る $^{1), 13)}$.

このように操作圧力によって溶質の排除率が変化する ことは，4.(1) の実験結果からわかるように, 水透過速 度が関与しているとも考えられる．このように仮定する と圧力以外の操作因子で水透過速度に変化をもたせて, その排除率特性を知ることは, 溶質の輸送機構を論じる 際にも有用な知見を与えることになるだろう. その因子 としては, 水の粘度を大きく左右する温度をまず最初に あげなければならない.こうした観点から，本節では排 除率に及ぼす操作圧力と 操作温度の影響を 比較検討し た.

Fig. 9 に操作温度を変数とした場合の操作圧力と排 除率の関係を示す. 対象とした溶液は, $10^{-3} \mathrm{~mol} / l$ の

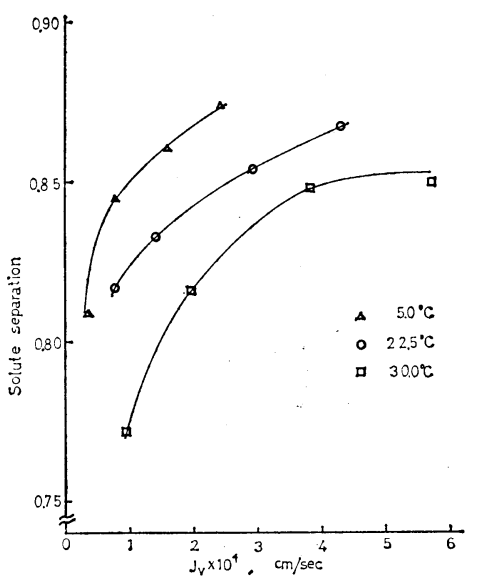

Fig. 10 Solute separation as a function of $J_{v}$ at various operating temperature. Conditions : $10^{-8} \mathrm{M}$ $\mathrm{NaCl}$ feed solution (Membrane $\mathrm{K}-311$ ). 
$\mathrm{NaCl}$ 溶液であり, 温度範囲は 5.0 $\sim 30.0^{\circ} \mathrm{C}$ である. 操作圧力 $5.0 \mathrm{~kg}$ $/ \mathrm{cm}^{2}$ における $22.5^{\circ} \mathrm{C}$ と $5.0^{\circ} \mathrm{C}$ と における排除率が逆転しているのを 除けば, 高温よりも低温におけるほ らが排除率が高い. Fig. 9 の結果 を操作圧力にかえて水透過速度をと って, 排除率との関係を示したのが Fig. 10 である.このような変換を 行うと, 前述した低圧領域における 排除率の逆転現象も解消して, 操作 温度と排除率との関係はよりいっそ う明確になる.つまり同一水透過速 度であっても, 温度が高くなるにつ れて排除率は低下する。

以上のように, 結果的に同一の水 透過速度を与える操作を行っても，

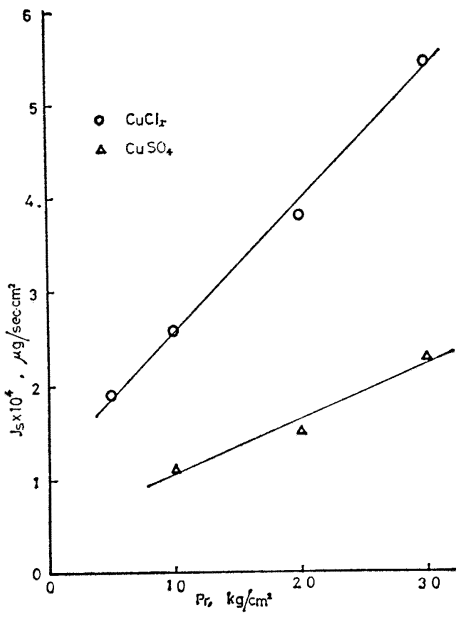

Fig. $12 J_{s}$ vs. $P r$ for $\mathrm{Cu}$. Conditions: $10^{-3} \mathrm{M}$ feed solution, temp. $22^{\circ} \mathrm{C}$ (Membrane $\mathrm{K}-402$ ).

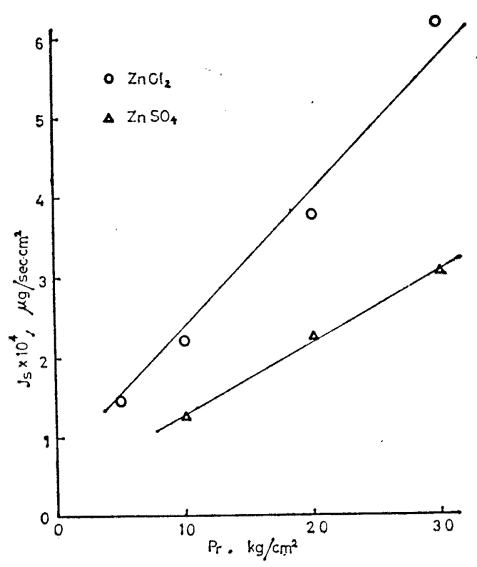

Fig. $13 J_{s}$ vs. $P_{r}$ for $\mathrm{Zn}$. Conditions: $10^{-8} \mathrm{M}$ feed solution, temp. $22^{\circ} \mathrm{C}$ (Membrane $\mathrm{K}-402$ ).
その速度の変化を引き起す因子が圧力であるか, 温度で あるかによって排除率の変化に関してはまったく逆の傾 向を示すということが明らかになった。この現象につい ては, 排除率よりも溶質透過速度の変化という点から論 じた方が適切であると思われるので，その考察は次節で 行う.なお, 比較的高濃度な $\mathrm{NaCl}$ 溶液に対しては, 前 述の Agrawal らの研究があるが, 希薄溶液については 言及していない.

b）溶質透過速度

前節では，溶質透過をたんに排除率で表示して，操作 因子との関連を述べたが，溶質の膜輸送機構に検討を加 える意味で, 排除率と水透過速度の両者から定まる溶質 透過速度に着目した.

一定温度条件下における 溶質透過速度と操作圧力（5

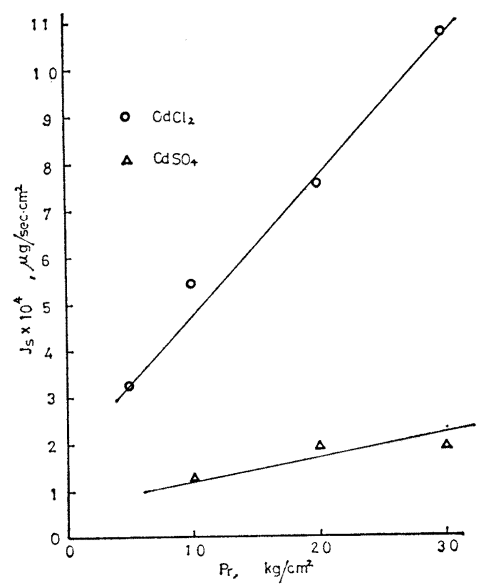

Fig. $11 J_{s}$ vs. $P_{r}$ for Cd. Conditions : $10^{-3} \mathrm{M}$ feed solution, temp. $22^{\circ} \mathrm{C}$ (Membrane $\mathrm{K}-402)$. $\sim 30 \mathrm{~kg} / \mathrm{cm}^{2}$ ) との関係を種々の金属イオン, 金属塩に 対して求めた結果を Fig. 11〜13 に示す. 横軸は有効 操作圧力, 縦軸は溶質透過速度を表わす. これらの図よ りわかるように, 溶質透過速度と有効操作圧力とはほと んど直線関係を保っている.ということは, 前述のよう に有効操作圧力と水透過速度が比例関係にあることとあ わせて考えると, 式 (9) でもって溶質透過速度を表示 することができる. 直線の傾きおよび縦軸切片ともに溶 質によって異なる. 同一金属種であっても, 化合物形態 により式 (9) の諸係数に差があり, 硫酸塩に比較して 塩化物の方が透過性が高い.

次に, 溶質透過速度を操作温度の面からその特性を求

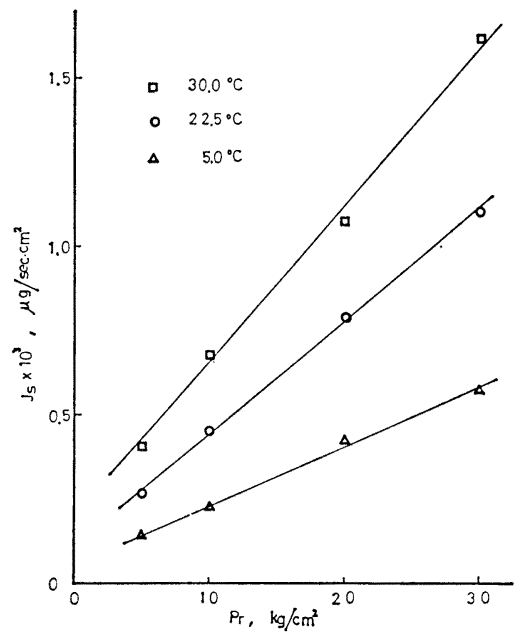

Fig. $14 J_{s}$ vs. $P_{r}$ at various operating temperature. Conditions : $10^{-8} \mathrm{M}$ $\mathrm{NaCl}$ feed solution (Membrane $\mathrm{K}-311)$. 


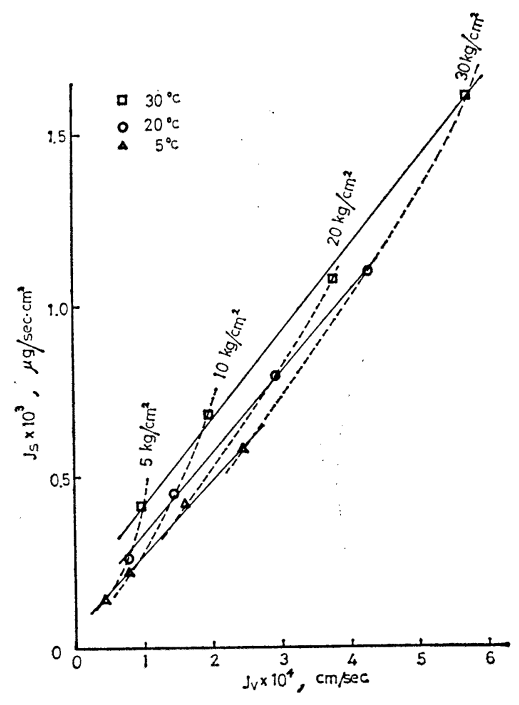

Fig. $15 J_{s}$ vs. $J_{v}$ at various operating temperature and pressure. Conditions : $10^{-8} \mathrm{M} \mathrm{NaCl}$ feed solution (Membrane $\mathrm{K}-311$ ).

めた結果を述べる. 対象とした溶液は, $10^{-3} \mathrm{~mol} / l$ の $\mathrm{NaCl}$ 溶液であり, 温度範囲 $5 \sim 35^{\circ} \mathrm{C}$, 操作圧力範囲 5 $\sim 30 \mathrm{~kg} / \mathrm{cm}^{2}$ における $\mathrm{NaCl}$ の透過速度を求めた. その 結果を Fig. 14 に示すが, この図より, 低温になるほ ぞ溶質透過速度が減少することが明らかである。また，

Fig. 15 から, 各操作温度における水透過速度に対する 溶質透過速度の増加率は，操作温度により多少異なる. このように, 水透過速度を変数としても, 細孔流に依存 する透過速度に差がみられるが, それ以上に, 各操作温 度における溶質透過速度の間に存在する差は, 拡散速度 の差がそのまま大きく寄与して現われたものである。

さらに, Fig. 15 における点線は, 一定操作圧力のも とでの温度変化に伴う水透過速度と溶質透過速度の関係 を表わしているが，この点線は，下に凹型の曲線を描い ており，外挿すると縦軸上のほぼ同一点に集中する。

\section{（3） 膜内拡散係数とその影響因子}

\section{a) 各種金属塩の膜内拡散係数}

Table $3 P_{s}$ of metallic ion at $22^{\circ} \mathrm{C}$ for membrane E$902\left(10^{-3} \mathrm{M}\right.$ solution)

\begin{tabular}{l|c}
\hline Solute & $P_{s}\left(\mathrm{~cm}^{2} / \mathrm{sec}\right)$ \\
\hline $\mathrm{NaCl}$ & $5.41 \times 10^{-9}$ \\
$\mathrm{CuCl}_{2}$ & $3.54 \times 10^{-9}$ \\
$\mathrm{ZnCl}_{2}$ & $3.59 \times 10^{-9}$ \\
$\mathrm{FeCl}_{3}$ & $2.16 \times 10^{-10}$ \\
$\mathrm{CrCl}_{3}$ & $9.50 \times 10^{-10}$ \\
\hline & (Cell type A)
\end{tabular}

膜内拡散係数の測定結果を

Table 3～5 に示す. Table 3 には, 塩化物溶液を対象と して金属の膜内拡散係数值を あげた．総体的に 1 価 $>2$ 価 $>3$ 価の順に值が小さくな る.また, Table 4 には,ア ルカリ金属として $\mathrm{Li}, \mathrm{Na}$, $\mathrm{K}, \mathrm{Cs}, \mathrm{Rb}$ の塩化物溶液を用 いて求めた金属塩の膜内拡散
Table 4 Diffusibility in water and membrane of $10^{-8} \mathrm{M}$ alkali chloride (Membrane $\mathrm{K}-401$ ).

\begin{tabular}{l|c|c|c}
\hline Solute & $\begin{array}{c}\text { Cation stokes } \\
\text { radius }(\AA)\end{array}$ & $\begin{array}{c}D_{s^{14}}\left(\mathrm{~cm}^{2} / \mathrm{sec}\right) \\
\left(25^{\circ} \mathrm{C}\right)\end{array}$ & $\begin{array}{c}P_{s}\left(\mathrm{~cm}^{2} / \mathrm{sec}\right) \\
\left(22^{\circ} \mathrm{C}\right)\end{array}$ \\
\hline $\mathrm{LiCl}$ & 2.54 & $1.345 \times 10^{-5}$ & $2.11 \times 10^{-7}$ \\
$\mathrm{NaCl}$ & 1.95 & $1.585 \times 10^{-5}$ & $2.54 \times 10^{-7}$ \\
$\mathrm{KCl}$ & 1.33 & $1.964 \times 10^{-5}$ & $2.75 \times 10^{-7}$ \\
$\mathrm{RbCl}$ & 1.27 & $2.024 \times 10^{-5}$ & $3.16 \times 10^{-7}$ \\
$\mathrm{CsCl}$ & 1.27 & $2.013 \times 10^{-5}$ & $2.96 \times 10^{-7}$ \\
\hline \multicolumn{2}{|c}{}
\end{tabular}

係数を示す.この結果, $\mathrm{Rb}>\mathrm{Cs}>\mathrm{K}>\mathrm{Na}>\mathrm{Li}$ の順 で，原子番号の一番小さい $\mathrm{Li}$ の透過性が最低である. 透過性を金属イオンの物理化学的特性と対応させるため に, Table 4 には, 水中拡散係数, ストークス半径など をも同時に載せた.これによると, 電導度あるいはゾー ン電気泳動によって得られた結果から算出された実効イ オン半径 (ストークス半径) の大きさとの対応関係がよ いようである.ささらに，水中拡散係数とはきわめてよく 対応しており，拡散過程における金属と膜との間の相互 作用に関しては, 金属種間には透過順位が変わるほど大 きな違いが存在しないものと推察される.このようなア ルカリ金属塩の透過順位の特性は, 塩化物に限らず硫酸 塩や硝酸塩についても該当すると思われる (Table 6 参 照).

次に, 同じ金属でも水に溶解させる場合の化合物形態 により，金属の膜内拡散係数が変化するかどうかを明ら かにするために, 塩化物, 硫酸塩, 硝酸塩の 3 種の化合 物について比較した. Table 5 から, 全般的に透過性 の順は, 硝酸塩>塩化物>硫酸塩となる. とりわけ, ア ルカリ金属塩では, 硫酸塩の透過が他の 2 つ塩にくら べてきわめて小さく, 膜内拡散係数では他の塩のそれの 1/10 以下といら值である. これに対して, 2 価の金属塩 においては, 硝酸塩と他の塩との差がとくに大きく, 塩 化物と硫酸塩との間には, アルカリ金属におけるほどの

Table 5 Diffusibility in water for heavy metal $\left(5 \times 10^{-3} \mathrm{M}\right.$ solution) at $22^{\circ} \mathrm{C}$ (Membrane $\mathrm{K}-402)$.

\begin{tabular}{c|c|c|c}
\hline Solute & Compound & $\begin{array}{c}P_{s}\left(\mathrm{~cm}^{2} / \mathrm{sec}\right) \\
\text { (by diffusion) }\end{array}$ & $\begin{array}{c}P_{s}\left(\mathrm{~cm}^{2} / \mathrm{sec}\right) \\
\text { (by reverse osmosis) }\end{array}$ \\
\hline $\mathrm{Cu}$ & $\mathrm{CuCl}_{2}$ & $5.29 \times 10^{-9}$ & $4.09 \times 10^{-9}$ \\
$\mathrm{Ni}$ & $\mathrm{NiCl}_{2}$ & $2.33 \times 10^{-9}$ & - \\
$\mathrm{Zn}$ & $\mathrm{ZnCl}_{2}$ & $4.02 \times 10^{-9}$ & $1.88 \times 10^{-9}$ \\
$\mathrm{Cd}$ & $\mathrm{CdCl}_{2}$ & $3.60 \times 10^{-9}$ & $3.09 \times 10^{-9}$ \\
\hline $\mathrm{Cu}$ & $\mathrm{CuSO}_{4}$ & $2.61 \times 10^{-9}$ & $1.48 \times 10^{-9}$ \\
$\mathrm{Ni}$ & $\mathrm{NiSO}_{4}$ & $3.04 \times 10^{-9}$ & - \\
$\mathrm{Zn}$ & $\mathrm{ZnSO}_{4}$ & $2.39 \times 10^{-9}$ & $1.01 \times 10^{-9}$ \\
$\mathrm{Cd}$ & $\mathrm{CdSO}_{4}$ & $1.30 \times 10^{-9}$ & $1.48 \times 10^{-9}$ \\
\hline $\mathrm{Cu}$ & $\mathrm{Cu}\left(\mathrm{NO}_{3}\right)_{2}$ & $10.57 \times 10^{-9}$ & - \\
$\mathrm{Ni}$ & $\mathrm{Ni}\left(\mathrm{NO}_{3}\right)_{2}$ & $9.73 \times 10^{-9}$ & - \\
$\mathrm{Zn}$ & $\mathrm{Zn}\left(\mathrm{NO}_{3}\right)_{2}$ & $8.88 \times 10^{-9}$ & - \\
$\mathrm{Cd}$ & $\mathrm{Cd}\left(\mathrm{NO}_{3}\right)_{2}$ & $9.31 \times 10^{-9}$ & - \\
\hline
\end{tabular}

(Cell type B) 
Table 6 Diffusibility in water and membrane of $5 \times 10^{-8} \mathrm{M}$ alkali salts (Membrane $\mathrm{K}$ -403 )

\begin{tabular}{c|c|c}
\hline Solute & $\begin{array}{c}P_{s}\left(\mathrm{~cm}^{2} / \mathrm{sec}\right) \\
\left(22^{\circ} \mathrm{C}\right)\end{array}$ & $\begin{array}{c}D_{s^{14}}\left(\mathrm{~cm}^{2} / \mathrm{sec}\right) \\
\left(25^{\circ} \mathrm{C}\right)\end{array}$ \\
\hline $\mathrm{KCl}$ & $3.58 \times 10^{-8}$ & $1.933 \times 10^{-5}$ \\
$\mathrm{LiCl}$ & $2.94 \times 10^{-8}$ & $1.323 \times 10^{-5}$ \\
\hline $\mathrm{K}_{2} \mathrm{SO}_{4}$ & $3.00 \times 10^{-8}$ & - \\
$\mathrm{Li}_{2} \mathrm{SO}_{4}$ & $2.20 \times 10^{-0}$ & - \\
\hline $\mathrm{KNO}_{8}$ & $1.14 \times 10^{-7}$ & $1.866 \times 10^{-5}$ \\
$\mathrm{LiNO}_{8}$ & $7.87 \times 10^{-8}$ & $1.289 \times 10^{-5}$ \\
\hline \multicolumn{2}{|c}{ (Cell type B) }
\end{tabular}

差はない.この ように, 金属種 によらず, 金属 イオンあるいは 金属塩の膜内拡 散を規定する因 子として陰イオ ンの果たす役割 は大きい.

さらに, Ta-

ble 6 に示した

ように, アルカリ金属塩の水中における拡散係数は，塩 化物>硝酸塩であり，塩化物と硝酸塩については，その 特性が膜内と水中とでは異なり，膜中での硝酸イオンの 透過が顕著である.

b）濃度および温度の影響

膜内払散係数を支配する影響因子として, 濃度と温度 とを久かすことはできない，濃度依存特性は， $\mathrm{LiCl}$, $\mathrm{NaCl}, \mathrm{KCl}$ の各水溶液について求めた. 濃度を $10^{-3}$, $5 \times 10^{-3}, 10^{-2}, 5 \times 10^{-2}, 10^{-1} \mathrm{~mol} / l$ の 5 段階に変化させ てえた膜内拡散係数を Fig. 16 亿示す. 低濃度域では 濃度の影響を強く受けるが, $5 \times 10^{-2} \mathrm{~mol} / l$ 以上になる と，ほぽ一定值に近ゔく傾向がうかがわれる．また，

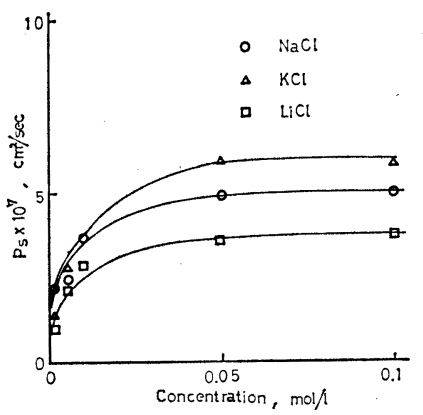

Fig. 16 Effect of concentration on $P_{s}$ for salt at $22^{\circ} \mathrm{C}$ (K-403 Membrane).

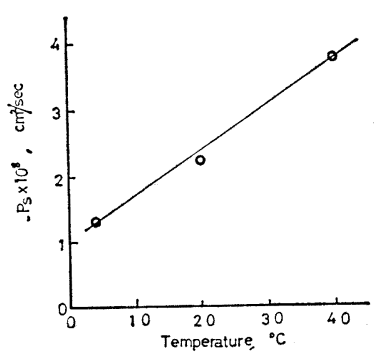

Fig. 17 Effect of temperature on $P_{s}$ for Cd. Conditions : $10^{-8} \mathrm{M} \mathrm{CdCl}_{2}$ solution(E -905 Membrane).
Fig. 17 には, 5 40 ${ }^{\circ} \mathrm{C}$ の温 度 範囲にお ける温度と膜内拡散 係数の関係を示す. 温度の影響はかなり 大きく, $40^{\circ} \mathrm{C}$ での 膜内拡散係数柱, 20 ${ }^{\circ} \mathrm{C}$ でのそれの約 1.7 倍である. 通常, 液 相での拡散係数の温 度影響は, Erying の式あるいは実験式 を用いて知ることが できるが, いゔれの 式でも $1^{\circ} \mathrm{C}$ の温度 上昇につき拡散倸数 は約 $3 \%$ 増加すると いら結果が得られて いる ${ }^{10)}$. 膜内拡散係 数の場合も, 本実験 結果からほぼ同様な 関係が成立している ものと思われる.

\section{（4）輸送式の圧力非依存項の検討}

定性的には式（9）で表示した溶質輸送式が成り立つ ことはすでに記した実験結果からほぼ明らかであるが, ここでは定量的な検討を一部行う.その一つの方法とし て水透過速度と溶質透過速度の実測值より外插によって 式 (9) の右边第一項を求め, これより算出した膜内拡 散係数と拡散セルを用いて求めた膜内拡散係数を比較す る. $\mathrm{Cu}, \mathrm{Cd}, \mathrm{Zn}$ の 3 種の溶質に対する結果を，Table 5 に示す. 加圧時と非加圧時における膜の厚さの変化や膜 面近傍における流動特性が逆浸透装置と拡散セルではす こし異なることなどを考慮しても，全体的に拡散セルで 求めた膜内拡散係数のほうがやや大きくなるなど定量的 にはまだ不十分なところが残る。

\section{5. 結言}

本研究では, 比較的単純な逆浸透モデルを提示し, あ わせて低濃度の電解質金属塩を用いて実験を行った。こ こで，低濃度溶液を対象にしたのは，浸透圧その他の溶 液特性にかかわる因子の取扱いに対する繁雑さを避ける ことができる点が大きな理由であり，また同様に主とし て電解質金属塩を用いたのも十分ではないがある程度こ れら金属塩の水中での存在状態や特性值などが知られて いると考えたからである．したがって，対象とした溶質 も単一金属塩であり，実廃水で問題となる多成分系につ いては，一応本論文では扱わなかった。これについては 今後の研究課題である.このような背景のもとに, 従来 はそれぞれ単独にしか議論されえなかった圧力と温度の 2 つの操作因子を中心にして，それら因子と逆浸透膜特 性との関連を明らかにしつつ, 提示したモデルの妥当性 にも巨視的な観点から検討を加えた結果，以下の知見が えられた。

（1）本実験で用いた希薄溶液の場合，水の透過速度 は基本的には，式（11）にて表示することができる.水 透過係数，Aは，温度によって変化する.この $A$ 值は, 純水の場合は，液温に対応する粘度との間に完全な反比 例の関係が成り立っている. しかし, 水溶液の場.合に は，この関倸が成り立たず，この理由としては，吸着な ど温度の影響を受けやすい作用が膜と溶質あるいは溶液 との間に生じているためと推察される。

（2）排除率に及ぼす圧力と温度の 2 つの操作因子の 影響が明らかになった．すなわち，圧力が低くなると排 除率は低下し，また，温度が高くなると排除率が低下す る. 両因子は水透過速度を大きく左右する点で共通して いるが，排除率に対しては，同一水透過速度であっても その効果は異なる. 
（3）（2）の事項をさらに明確にするために，溶質透 過速度と圧力および温度という2 操作因子との関連性を 水透過速度を通して求めた. この結果, 圧力変化に対応 する水透過速度と溶睤透過速度の間には直線関係が成立 するのに対して, 温度変化に対応する水透過速度と溶質 透過速度との間には, 同様の関係はみられない。

（4）溶質透過速度に占める圧力依存項の大きさは， 溶質種によって異なり, とくに同一金属種でも化合物形 態による相異が大きく, 塩化物に比し, 硫酸塩の非透過 性湿影著である. また, 定量的には不充分であるが，低 圧領域における溶質透過速度は式（9）で表示しうる。

（5）膜透過における拡散流の重要性にかんがみて, 膜内拡散係数, $P_{s}$ を規定する主要な因子について，そ れらが $P_{s}$ に及ぼす影響を明らかにした結果, 温度に関 しては, 液相での拡散係数に対する Erying の式などが 適用しうることが，また，溶液濃度の影響に関しては， ある濃度以上になればほとんど影響を受けないことが判 明した。

（6）溶質種による膜内拡散係数， $P_{s}$ の違いに検討 を加えた結果, 金属では, 1 価 $>2$ 価 $>3$ 価の順で多価 になるなど $P_{s}$ は小さくなる. この中で金属イオン, と りわけアルカリ金属ではストークス半径がおおいに関与 していることや, これらが水中の拡散係数の順位と合致 している点, さらには同一金属では, 塩化物と硝酸塩と では水中と膜内の易動性の順位が逆転するなどの結果が えられた。

\section{【記 号】}

$$
\begin{aligned}
& A: \text { 水透過係数 } \\
& A_{m}: \text { 膜の断面積 } \\
& a: \text { 式 (3) のパラメーター } \\
& b: \text { 式 (3) のパラメーター } \\
& C: \text { 溶質の濃度 } \\
& C^{\prime}: \text { 水の濃度 } \\
& \Delta C: C_{h}-C_{l} \\
& D: \text { 液相抗散係数 } \\
& J: \text { 流束 } \\
& J_{v}: \text { 透過水の流束 } \\
& K_{w}: \text { 式 (7) で定義される係数 } \\
& k_{s}: \text { 溶質の拡散に対する膜係数 } \\
& k_{v}: \text { 細孔流に対する膜倸数 } \\
& k_{w}: \text { 水の抗散に対する膜係数 } \\
& M: \text { 分子量 }
\end{aligned}
$$

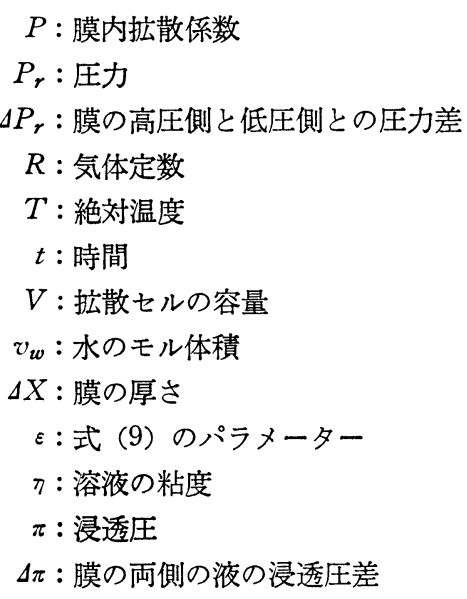

添 字

$$
\begin{aligned}
& s: \text { 溶質 } \\
& w: \text { 純水 } \\
& i: \text { 抗散セルの溶液側 } \\
& p: \text { 抗散セルの純水側 } \\
& d: \text { 拡散流 } \\
& f: \text { 粘性流 } \\
& h: \text { 膜の高圧側 } \\
& l: \text { 膜の低圧側 }
\end{aligned}
$$

1) Lonsdale, H.K., U. Merten and R.L. Riley : J. Appl. Polymer Sci., 9, 1341 (1965).

2) Michaels, A.S., H.J. Bixler and R.M. Hodges, Jr. : J. Colloid Sci., 20, 1034 (1965).

3) Riley, R.L., H.K. Lonsdale, C.R. Lyons and U. Merten : J. Appl. Polymer Sci., 11, 2143 (1967).

4) Sherwood, T.K., P.L.T.Brian and R.E. Fisher : Ind. Eng. Chem. Fundamentals, 6, 2 (1967).

5) 中根・石坂 : 日本海水学会誌, 26, 11 (1972).

6) Spiegler, K.S. and O. Kedem : Desalination, 1, 311 (1966).

7) Yasuda, H., C.E. Lamaze and A. Peterlin : J. Polymer Sci., 9, 1117 (1971).

8) Sourirajan, S. : Reverse Osmosis, Logos Press (1970).

9) Merten, U. : Desalination by Reverse Osmosis, M.I. T. Press (1966).

10）佐藤：物性定数推算法, 丸善 (1972).

11) Govindan, T.S. and S. Sourirajan : Ind. Eng. Chem. Proc. Des. \& Develop., 5, 422 (1966).

12) Agrawal, J.P. and S. Sourirajan : Ind. Eng. Chem. Proc. Des. \& Develop., 8, 439 (1969).

13) Reid, C.E. and E.J. Breton : J. Appl. Polymer Sci., 1, 133 (1959).

14) 日本化学会編：化学便覧, 丸善.

(1976.8.19 ·受付) 